Island Studies Journal, Vol. 1, No. 1, 2006, pp. 109 -124

\title{
Eden in Peril: Impact of Humans on Pacific Island Ecosystems
}

\author{
Moshe Rapaport \\ University of Hawai 'i Center, West Hawai 'i \\ Kealakekua, Hawai 'i, USA \\ rapaport@hawaii.edu
}

\begin{abstract}
Islands have often been cited as models of human impact upon the environment. With high rates of endemism and other unique characteristics, island ecosystems are subject to dramatic perturbation. The arrival of humans in Near Oceania during the Pleistocene led swiftly to a series of fauna extinctions. In the New Guinea Highlands clearing and tending of wild plants gave rise to tree and root crop agriculture, intensive cultivation technology, and anthropogenic grasslands. By 3600 BP (Before Present), Lapita settlers had reached Remote Oceania, leading to deforestation and declines in birds and other species. European contact introduced new biota and new technology, with significant consequences for island environments and societies. Questions have been raised concerning the impact of climate change on island ecosystems. Population growth plays a significant role in environmental degradation, though not necessarily as a proximate cause. The Tikopian arboriculture system provides one of several Oceanic models of sustainability.
\end{abstract}

Keywords: human impact, islands, island ecosystems, Oceania, sustainability

Copyright ( 2006 Institute of Island Studies, University of Prince Edward Island, Canada.

\section{Introduction}

When the Dutch explorer Roggeveen happened upon Easter Island (Rapa Nui) in 1722, he remarked upon its wasted appearance, covered with withered grass and other scorched or burnt vegetation (Sharp, 1970: 93). Subsequent work by archaeologists has uncovered a tragic history of isolation, demographic growth and deforestation ending in clan warfare and the destruction of the pre-European society (Kirch, 2000). Bahn \& Flenley (1992) present Easter Island as a model for the earth as a whole: mounting population numbers, pressure on natural resources, followed by a "crash".

Landscape change over time has become an important topic of current research (Fisher \& Feinman, 2005). There is growing awareness that human activity has generated a wide variety of environmental changes and that assessment is impossible without attention to the long-term perspective. Some of the most critical problems in landscape change today and in the past arose in situations of frontier expansion (Cronon, 1983; Worster, 1992). Islands have a particular tendency toward species endangerment and habitat degradation, and the environmental consequences of human colonization on islands are especially worthy of our attention. 
The following questions will be addressed here: (1) In what respect are island ecosystems unique? (2) Why do island ecosystems tend to become quickly and severely endangered following the arrival of humans? (3) What range of environmental impacts has occurred over long periods of time, and across diverse island groups? (4) Can environmental impact be attributed to natural causes, rather than human agency? (5) To what extent can environmental impact be attributed to population growth? (6) Why have island societies not taken steps to prevent environmental degradation? (7) Is it possible for human presence on islands to be "sustainable”?

\section{Island Ecosystems}

Islands have been particularly instructive in ecosystem studies because limited area and isolation combine to make evolutionary patterns stand out starkly. Marine iguanas, giant tortoises, ground-nesting crows, and carnivorous caterpillars are merely a few of the remarkable fauna found on islands. Islands have served as "primers of evolutionary ecology, helping scientists master enough vocabulary and grammar to tackle the more complex prose of continents” (Quammen, 1996: 19). Wallace's Island Life and Darwin's Origin of Species are among the landmark studies inspired by islands, as was MacArthur and Wilson's Theory of Island Biogeography (1967).

Geographical isolation may be considered the "flywheel of evolution" (Quammen, 1996: 128); hence islands have relatively high rates of endemism. Hawai'i has over $90 \%$ rates of species endemism in many taxa. Signature features of island biota include: dispersal ability, (in some cases) loss of dispersal ability, gigantism, dwarfism, endemism, founder effect, genetic drift, adaptive radiation, loss of defensive adaptations, reduction of genetic diversity, disharmony, and species impoverishment. (Coral atolls - and coastal ecosystems in general - are notable exceptions to these generalizations, being populated by biota which are good dispersers.) Due to several of these unique evolutionary features island biota are highly vulnerable to extinction following human interference (Quammen, 1996; Whittaker, 1998).

For fauna on remote islands, the arrival of humans heralded a biological catastrophe (Anderson, 2002). Martin and Steadman (1999) refer to a blitzkrieg of extinctions following human colonization. Ecological contributing factors may include limited geographical space, smaller numbers of individuals, loss of defensive adaptations (lack of thorns, spines, and toxins among island flora; loss of flight, protective coloration, warning mechanisms, and wariness ${ }^{1}$ among fauna), and ecological release of alien species (lacking pests, predators, and competitors); and reduction in genetic diversity.

\footnotetext{
${ }^{1}$ Early explorers were amazed by the "tame" island fauna; Quammen (1996: 206) proposes the term ecological naïveté.
} 


\section{The Dreadful Syncopation ${ }^{2}$}

It has been estimated that in any remote Pacific Island with a "respectable fossil record" one can expect to find at least two or three times the number of land bird species before human contact than afterward (Martin \& Steadman, 1999). Radiocarbon dating of fossils throughout the Pacific shows that avian extinctions occurred within a century after human colonization, indicating that extinctions were to some degree density independent (Anderson, 2002). Losses in native snails, insects, and other fauna have also been enormous. Flora may be more resistant to extinction than fauna, but many plants have also been endangered (Cox \& Elmqvist, 2000).

Excavations in Ewa Plain sinkholes on Oahu show that the decline of avian fauna occurred around the time of Polynesian colonization of Hawai'i, concurrent with a rapid loss of lowland forest. This habitat destruction occurred prior to any occupation of the Ewa Plain, and prior to forest burning. Athens et al. (2002) suggest that the Polynesian rat, Rattus exulans (predominantly a plant-eater) was to blame. Lacking predators and having a high fertility rate, it could have covered the island of Oahu up to its maximum elevation range in a decade. Feeding on seed, fruit, seedlings, new leaves, and invertebrates critical to plant pollination and nutrition, it is suspected of devastating lowland forests and dependent fauna. $R$. exulans is also blamed for ecosystem collapse in New Zealand a thousand years before permanent settlement by Maori colonizers (Sessions, 2003).

Forest clearance by humans exacerbated the effects of rats, pigs, and other introductions. Tropical soils are thin, particularly on hilly volcanic slopes. Under conditions of heavy rainfall, soil erosion can be considerable, resulting in gullying and a "climax"3 savannahlike vegetation of fern, scrub, and grassland, known in Fiji as talasiga. This process is accelerated during hurricanes when immense amounts of rain can be unleashed during short periods; and can be a major cause of erosion after repeated forest burning. Similar cases of anthropogenic fernland and grassland have been documented in Palau, Yap, Futuna, the Southern Cooks, French Polynesia, Hawaii, and other Pacific Islands (Bayliss-Smith, 1988: 31-38; Kirch, 1994: 225-227). ${ }^{4}$

\section{Pleistocene Colonization}

Settlement sites in the uplifted Huon Peninsula, New Guinea, have been dated to 40,000 years ago. Due to polar ice cap expansion sea levels were lower by up to 130 meters, exposing continental shelves of Sunda (Greater Southeast Asia) and Sahul (Greater Australia). Crossing the boundary between these two biogeographic regions (Wallace's Line, between Bali and Lombok), early colonists entered a pristine and very different

\footnotetext{
${ }^{2}$ After Martin \& Steadman (1999), referring to the conjunction of human settlement and faunal extinctions.

${ }^{3}$ The terms "climax" and "terminal state" are used by Kirch (1994: 226). However, these states can be avoided and perhaps even reversed, as indicated by the case of Tikopia, discussed below.

${ }^{4}$ Nunn (1999) argues that talasiga and many other supposedly anthropogenic grasslands in the tropical Pacific may in fact be climatogenic; this point of view is further discussed in a separate section below.
} 
ecosystem unaccustomed to human predators. Reliance on flightless birds and large animals would have been an important survival strategy for early settlers.

The New Guinea Highlands were home to at least seven species of marsupial megafauna belonging to Diprotodon or wallaby species. The largest weighed up to 200 kilograms and was similar to Australia's marsupial rhinoceros. All of these became extinct by the early Holocene. Similarly in Australia, ${ }^{5}$ none of the original megafauna survived past the end of the Pleistocene. While this was a time of global climate change, the contributing effect of hunting pressure and human-induced fires causing grasslands expansion is likely to have been significant (Flannery, 1994; Kirch, 2000: 72-74).

Pollen and charcoal data suggest limited clearing and burning beginning at least 20,000 years ago. Early archaeological sites dating to have revealed remains of edible foods, including Canarium, Pandanus, Cocos, Metroxylon (sago), Alocasia, and Colocasia. Phalangers (tree climbing marsupials) are native to New Guinea, and appear to have been introduced throughout Near Oceania ${ }^{6}$ over 6,000 years ago (Kirch, 2000). ${ }^{7}$ Forest clearance, with consequent redeposition of upland sediments, opened possibilities of productive agriculture, improving the likelihood of demographic success (Anderson, 2002). Arboreal-based economies, including root-crop components, may have developed soon after colonization (Latinis, 2000). ${ }^{8}$

\section{Agricultural Intensification}

Palaeo-environmental studies (based on sediment and pollen data) show signs of deforestation and erosion for at least 7,000 years in New Guinea. An extensive network of channels excavated at Kuk in the New Guinea Highlands dates to 9,000 years ago, with features including pits, stake holes, mounds, and ditches; along with taro starch grains and banana phytoliths. Taro, bananas, sugar cane, and breadfruit, as well as numerous other crops are believed to have been cultivated and domesticated in New Guinea (Kirch, 2000: 79; Neumann, 2003; Denham, 2005) ${ }^{9}$.

The net effect of long term shifting cultivation was continuing replacement of forest by secondary growth "as cultivation expanded to its local limits and turned back on itself in a tightening cycle of more frequent clearances separated by ever-shortening fallow periods” (Golson, 1997: 41). Pollen sequences chronicle deforestation and expansion of

\footnotetext{
${ }^{5}$ Though usually considered a continent, Australia exhibits many insular features and was actually a single land mass with New Guinea during the Pleistocene.

${ }^{6}$ New Guinea to the Southeast Solomons. In contrast to Remote Oceania, water gaps are less than $90 \mathrm{~km}$ and islands are inter-visible (Green, 1991).

${ }^{7}$ It is highly unlikely that these tree-dwelling mammals could have translocated across these substantial ocean gaps without human assistance.

${ }^{8}$ Bailey et al. (1989) question whether hunting and gathering alone was ever a viable strategy in tropical rain forests.

${ }^{9}$ The long history of agriculture in New Guinea may explain why this island contains an extraordinarily high linguistic diversity. New Guinea contains 1000 out of the modern world's 6,000 languages, with dozens of language isolates or families with no demonstrable relationship to any other language (see Diamond \& Bellwood, 2003).
} 
anthropogenic grasslands, with a consistent rise in Casuarina, planted in an attempt to rehabilitate degraded soil. Pig (Sus scrofa) bones are only sparsely present in the Highlands prior to the past thousand years, though there are claims for the presence of pigs dating to $8000 \mathrm{BP}$ (Kirch, 2000: 125).

Malaria may have constrained settlement in lowland Melanesia, where (even on large resource-rich islands) populations never reached high densities comparable to the Highlands. ${ }^{10}$ At least two species of malaria probably arrived with the first settlers of Sahul, reducing natural increase due to differential mortality among pregnant mothers and children (Kirch, 2000: 83-84). High population densities developed primarily in the New Guinea highlands, where malaria is absent or has little effect. Endemic malaria and scattered populations in lowland Melanesia may have facilitated settlement by Austronesian-speakers later on ${ }^{11}$ (Clark \& Kelly, 1993).

\section{The Lapita Expansion}

By around $3500 \mathrm{BP}$, a new wave of Pacific colonization settled coastal sites in the Bismarck Archipelago and Remote Oceania, extending to Tonga, Samoa, and beyond. Archaeological and linguistic evidence indicates that these were Austronesian-speaking groups with an advanced maritime technology, unique settlement patterns, distinctive Lapita pottery, and a sophisticated agricultural heritage, including animal husbandry. While some models describe the Lapita expansion as "an express train", there is likely to have been considerable mixing with local cultures (Spriggs, 1999; Gibbons, 2001).

The demographic history of Remote Oceania is one of remarkable growth. Large, dense populations arose repeatedly within only 1,000 to 2,500 years. Polynesian, as well as some Micronesian and Melanesian societies, were united politically as chiefdoms ranging from a few thousands to tens of thousands of people (Kirch, 2000: 342, note 79). In the simplest societies distinctions between chief and commoner were minimal. In Hawai'i an "archaic state" (Kirch, 2000: 289) and largest of the chiefdoms at the time of European contact - chiefs were internally ranked, marked with feathered cloaks and insignia of rank; large-scale corvée labour was mobilized to build large temples and irrigation works; and commoner land rights were limited to usufruct (Kirch, 2000: 289-300).

Significant changes in sediment distribution and vegetation patterns developed as population density increased and settlement expanded inland. Anthropogenic change would have been severe on small, young islands with fragile soils (Anderson, 2002). In Mangaia (area $52 \mathrm{~km}^{2}$, settled $2500 \mathrm{BP}$ ) the central volcanic ridges had been completely denuded of the original forest cover by $1000 \mathrm{BP}$, replaced by infertile fernlands. This may have been a key factor in the subsequent development of irrigation complexes on newly deposited alluvial basins. Competition for land became intense and leadership

\footnotetext{
${ }^{10}$ Miles (1997) suggests that scrub typhus may also have hindered human settlement.

${ }^{11}$ Clark \& Kelly argue that Gm (immunoglobulin) polymorphisms among Austronesian-speakers provided better adaptation to malaria, relative to those common among Non-Austronesian-speaking peoples.
} 
passed from hereditary to achieved chieftainship, along with the transformation of the agricultural cult of Rongo to a human-sacrificial war cult (Kirch, 1997).

\section{European Contact}

With the voyages of Cook (late $18^{\text {th }}$ Century), sexually transmitted diseases along with tuberculosis, smallpox, measles, and other infectious diseases spread quickly, decimating Pacific Island populations. Isolated from continental societies for millennia, Pacific Islanders had little immunity to the diseases of Eurasia and Africa. Historical demographic studies by Rallu (1990) have shown population declines of 2-3\% per year sustained over many decades, reducing some populations to a tenth of their former sizes. These losses were exacerbated by enslavement, blackbirding, and labour migration. In some areas, this may have paved the way for partial forest recovery (Brookfield \& Overton, 1988: 91).

However, introduced cattle, goats, pigs, and other animals soon multiplied to large numbers; filling niches that had been opened by depopulation, and extending into native forests. Exotic flora such as guava and clidemia in Hawai'i thrived in niches opened by grazing animals. Bird life, already reduced following the arrival of Polynesians, suffered additional predation by the European rat (R. rattus). In Hawai'i, mosquitoes (introduced in 1826) carried avian malaria. Cats, mongoose, and other animals were introduced to control rat populations, but these became pests in their own right, leading to further declines in native birds. International markets for sandalwood, kauri (Agathis australis), whales, seals, tortoiseshell, pearl oysters, and beche-de-mer brought further devastation to terrestrial and marine ecosystems (McNeill, 1990: 316-323).

In large islands, ranching and plantation crops triggered large-scale clearance of native forests. In New Zealand and Hawai'i, native islanders were deprived of much of their land, outnumbered by European immigrants. Mining has destroyed much of the land surface on Nauru, and has caused severe pollution in Melanesia. Nuclear testing has rendered many Micronesian atolls uninhabitable, displacing their populations. Young people are increasingly going abroad for schooling, work opportunities, and urban amenities; triggering a second wave of widespread fallowing on their home islands. Since exotic species are now entrenched, this does not necessarily translate into ecosystem recovery (McNeill, 1990: 336).

\section{Impact on Reef Ecosystems}

Fish bones and shellfish remains on Matenkupkum, New Ireland (35000 BP) may be the earliest evidence of marine exploitation in the world. ${ }^{12}$ Reefs and lagoons provided the main source of animal food for colonists of Pacific Islands up through the time of European contact. Reefs in the Southwest Pacific teem with thousands of fish species (declining to the east). Islanders relied heavily on inshore and benthic fish using hooks,

${ }^{12}$ Other sites of early shellfish exploitation are presented in Volman (1978). 
nets, spears, traps, and poisons. Pelagic fish such as tuna were caught by trolling the offshore coastal waters. Bivalves and gastropods were easily collected from lagoon floors. Other important marine foods included sea urchins, octopus, crabs, seaweeds, and green sea turtles (Kirch, 2000: 55-56).

Midden studies have documented progressive declines in species diversity and reduction of average age and size for fish, invertebrates, and sea mammal populations (Thomas, 1999). For many marine species, reproductive success declines dramatically when population drops below specific thresholds (the Allee effect). This applies particularly to sessile species, such as most bivalves, but mobile species can be affected as well. Coral reef fish especially vulnerable to such reductions include species that are sedentary or territorial; that gather from large areas into spawning aggregations at predictable locations and times; or that are characterized by sequential hermaphroditism, delayed maturation, slow growth rates, large adult size, and long life spans (Birkeland, 2004).

Following European contact growing populations, new fishing technology, and pollution from agriculture and land development has caused deceases in reef abundance, changes in reef community structure, deterioration of reef health, and a shift from an original dominance of corals to a preponderance of fleshy seaweed. The link between greenhouse gases, climate change, and worldwide coral bleaching is now "incontrovertible" (Hughes et al., 2003). Along low coasts made from unconsolidated material sea-level rise is likely to aggravate coastal erosion, overwash, and salinization of the fresh water lens. The coral atoll nation of Tuvalu has filed claims for international compensation over the impact of sea level rise (Connell, 2003).

\section{The Demographic Factor}

In her well known essay on agricultural change, Boserup (1965) has argued that growth in population does not necessarily lead to resource shortages (as predicted by Malthus); instead, population pressure spurs intensification and increases in production. This may be accomplished by reduction of fallow length and increased application of weeding, mulching, and other labour (cropping cycle intensification); though at the expense of efficiency (time per unit labour) and the environment. Alternatively, permanent modifications may be made to the landscape ("landesque" intensification); once in place, minimal additional labour may be required. Terraced pondfields provide the classic example (Kirch, 2000: 313-321).

Intensification has its limits, particularly in locations where irrigation is not feasible. As populations grow, fallow shortens (rendering the soil infertile) and the margin between production and consumption dwindles (diminishing available surplus). In Easter Island this led to severe deforestation and a collapse of the chiefly system which appropriated the surplus. In the more favorable endowed New Guinea Highlands population growth over several millennia was accommodated by landesque intensifications. Tiny Tikopia developed a sustainable arboriculture system, but even this could not accommodate endless growth (Kirch, 1997). 
When productivity levels or contentment levels fell below a certain point population control mechanisms inevitably came into play; either prior to, concurrent with, or subsequent to environmental degradation. In Tikopia the population was kept in check via chiefly sanctions, announced publicly during the annual ritual cycles (Firth, 1967; Kirch, 1997). Warfare reduced population growth in many precontact island societies, even if this was not with the conscious intent to reduce population pressure on resources. Following European contact the attractions of cities, cash employment, and migration opportunities provided a further avenue of population reduction throughout the Pacific Islands (Rapaport, 1999).

\section{Feeling the "Hand of God""13}

Nunn (1997) has challenged the routine assumption that human activity has been the major "villain" in environmental impact in Oceania. Nunn (2003a) argues that "for much of the post-settlement history of the Pacific Islands, humans were the 'victims' rather than the 'agents' of environmental change". According to this view damage due to forest clearance and species introductions may have been mere "marginal disruptions" for island ecosystems, with more significant and long-lasting changes caused by changes in climate and sea level. However, most researchers would probably agree that climate change along with a host of environmental variables interacted with humans in causing deforestation, erosion, and species extinctions.

Rolett and Diamond (2004) have reported on a study of 81 sites on 69 Pacific Islands Ranging from Yap to Easter Island, and from Hawai'i to New Zealand - correlating deforestation at the time of European contact with nine environmental variables. These included temperature, rainfall, age, tephra, Asian dust, elevation, area, distance (from the nearest land), and uplifted reef. Temperature and rainfall are primary determinants of plant growth rates; tephra and dust replenish soil with nutrients. These factors would be expected to provide resilience to perturbation. Area, distance, elevation, and uplifted reef pose barriers and help shield forests. Geologic aging leaches nutrients and predisposes toward deforestation.

Their statistical analyses showed that rainfall, area, elevation, uplifted reef, and ash (but not Asian dust) are indeed correlated with less deforestation; while latitude (a surrogate for temperature), geologic age, and distance were correlated with more deforestation. ${ }^{14}$ Comparing the variables for the islands studied, Easter Island had the third highest predictive "deforestation score" (exceeded only by Necker and Nihoa, which were both deforested and uninhabited at contact). Thus, Easter Island's collapse occurred "not because its people were especially improvident, but because they faced one of the Pacific's most fragile environments” (Rolett \& Diamond, 2004; also Hunter-Anderson, 1998; Rainbird, 2002).

\footnotetext{
${ }^{13}$ After Nunn (1997).

${ }^{14}$ Correlation results with forest replacement were similar, but not identical. See Rolett \& Diamond (2004).
} 


\section{Explaining Human Inaction}

Explaining human inertia in the face of mounting environmental deterioration (such as complete deforestation in Easter Island) poses a puzzle (Diamond, 2005). Why have past and present societies repeatedly failed to stop environmental degradation? One explanation involves discounting future gains relative to present day ones. Delays increase the chance that gains will fail to be realized at all, and reduce the opportunity to put gains to work in producing more gains. Demographic growth, resource mobility, and resource renewal rates are among the factors which affect temporal discounting (Smith \& Wishnie, 2000). Also relevant is the problem of collective action, occurring when an action is collectively costly, but individually beneficial; or vice versa (Hardin, 1968).

Societies fail to anticipate, perceive, or solve critical environmental problems for a variety of other reasons (Diamond, 2005: 503-514). Gradual changes in seasonal temperature, annual rainfall, and the extent of tree loss may not be recognized until it is "too late". Reluctance to recognize the reality of climate change today is a case in point. Even when a problem is identified, those with wealth and power may be unwilling to reduce their own consumption for the benefit of the less fortunate. It may difficult to enact policies that clash with strongly held values. Many people believe that technology has the capacity to solve any developing problems.

State economic development policies often conflict with landholding groups which hold customary jurisdiction, frustrating management efforts. Many Pacific Islanders still rely on traditional land and marine subsistence practices, often frustrating conservation efforts. Experiences with colonial administrations have made many island communities suspicious of any government initiatives affecting customary land, despite compensation (Saulei, 1994). Chiefly elite groups have manipulated environmental policies to suit their own interests (Turnbull, 2004). Increased involvement of the public in environmental education, monitoring and policy making will be necessary for successful conservation efforts in Pacific Island countries (Baines, 1994).

\section{Is Sustainability Possible?}

Kirch (1997: 35) cites Tikopia as "a model of the sustainable microcosm”. Though only $4.6 \mathrm{~km}^{2}$ in area, Tikopia has been home to as many as 1,700 people; its high population density level sustained through an arboricultural system that has replaced yet structurally mimics the multistory diversity of the tropical rain forest. The island is covered with nut and fruit trees, protecting and shading intensive understory plantings of aroids, yams, and other crops. Protein is obtained exclusively from the reef and open sea. Achieving sustainability, however, was a gradual and sometimes costly, historical process.

Archaeological studies show that the original settlers of Tikopia (around 900 BC) engaged in shifting cultivation and forest clearance, resulting in major erosion and sedimentation, changes in the composition of native biota, and the extinction of land and 
sea bird species. Only after a millennium of settlement are there indications of conversion from shifting cultivation to arboriculture. Pigs were deliberately eliminated to prevent damage to the gardens. The population was held in check through celibacy, prevention of conception, abortion, infanticide, sea-voyaging, and expulsion of segments of the population (Kirch \& Yen, 1982; Kirch, 1997).

The New Guinea Highlands have also been cited as a model of sustainability. Swampy highland valleys were drained using sophisticated ditch systems, heavy application of compost (up to 16 tons per acre), crop rotation with legumes which fix atmospheric nitrogen, timber plantings, and erection of terraces and soil retention barriers. Population growth was checked by war, infanticide, contraception, abortion, abstinence, and lactational amenorrhea. Limited power of "big-men” required that decisions are reached after lengthy discussions involving the entire community. This context may have supported "bottom-up problem-solving" sustaining agriculture in highland valleys for over 7,000 years (Diamond, 2005: 280-286). ${ }^{16}$

With European contact the decline of traditional warfare and birth controls, along with the introduction of new crops and new medicine, rapid population expansion occurred throughout the region, offset primarily via migration (Rallu \& Ahlburg, 1999; Rapaport, 1999). In Tikopia, growth was relieved only by land grants on other islands in the Solomons group; today, as many Tikopia live off-island as the 1,115 allowed by the Council of Chiefs to live on Tikopia (Kirch, 1997: 36). In Papua New Guinea, rapid population growth has resulted in migration to Highland and coastal towns, fuelling the growth of shantytowns and other urban problems (Connell, 1999).

In recent years, there has been a revival of traditional resource management systems in Oceania (Clarke, 1990). These efforts are often unworkable due to radical environmental changes over the past hundred years or so (Nunn, 2003b). They have, however, had significant success in the case of marine resources. Johannes (2002) reviews the widespread "renaissance" of community-based marine resource management in Oceania, citing examples from Samoa, Cook Islands, Fiji, Palau, Tuvalu, and Hawai'i (mainly in Moloka'i and Kahoolawe. Johannes (ibid.) credits this renaissance to recognition of dwindling resources, ecotourism potential of reefs, renewal of cultural pride, and renewed authority of customary laws and leadership in the decades following independence.

\section{Conclusion}

Island ecosystems have unique characteristics and are easily impacted by disturbance. Species extinctions, deforestation, and exotic invasions can occur rapidly following colonization by humans. Area, distance, temperature, rainfall, volcanic ash, and other factors play important roles in resilience to environmental degradation. Population

\footnotetext{
${ }^{16}$ Criticisms of Diamond's theses include Bailey (2005) and Shapiro (2005). The social ramifications of the Ipomoean Revolution in the New Guinea Highlands are discussed by Wiessner (2002).
} 
growth has increased pressure on island ecosystems, alleviated via intensification. At some point, however, demographic controls must inevitably come into play. Population pressure has been linked historically with expansionism and the formation of complex sociopolitical entities (Kirch, 1997: 316-321); and with migration and urbanization today.

Smith and Wishnie (2000) suggest that colonization of new habitats may be a strategy hominids evolved in response to Pleistocene temperature fluctuations. Settlers on Tikopia, as well as other Pacific Island populations, eventually developed stable and productive agronomic systems, but the original ecosystems were drastically transformed. In no case can the biota be restored to an original "pristine" state. ${ }^{17}$ Elsewhere as well forests, grasslands, reefs, and other habitats seen as natural may be temporary states on a dynamic continuum, subject to geomorphic and climatic shifts, as well as anthropogenic disturbance.

Brookfield (2001) writes that change occurs "when people find better ways of doing things". Farmers change their systems incrementally, transforming them while in use. Adaptation and innovation are keys to survival and successful change. In Hawai'i changing market pressures have made it increasingly difficult to keep land or labour in agriculture; and sugar land has been displaced by homes, resorts, and golf courses. Smaller Pacific Islands have resorted to MIRAB economies ${ }^{18}$ (Bertram, 1985). Whether these strategies are sustainable will depend on iterative evaluation of a range of environmental and other consequences; not on the ability to return to an "original” state.

\section{Acknowledgements}

Acknowledgements to Tim Bayliss-Smith (University of Cambridge), Frank Thomas (Marshall Islands Historic Preservation Office), Patrick Nunn (University of the South Pacific), and anonymous readers for reviewing this article; and to our librarians Laurel Gregory and Karen Au for interlibrary loan material.

\section{References}

Anderson, A. (2002) 'Faunal collapse, landscape change and settlement history in Remote Oceania', World Archaeology, Vol. 33, No. 3, pp. 375-390.

Athens, J.S., Tuggle, H.D., Ward, J.V. \& Welch, D.J. (2002) 'Avifaunal extinctions, vegetation change, and Polynesian impacts in prehistoric Hawai'i', Archaeology in Oceania, Vol. 37, No. 2, pp. 57-78.

Bahn, P. \& Flenley, J. (1992) Easter Island, Earth Island, London, Thames \& Hudson.

\footnotetext{
17 The notion of landscape as palimpsest is further developed by Fisher \& Feinman (2005).

${ }^{18}$ Economies dependent on MIgration, Remittances, Aid and Bureaucracy.
} 
Bailey, R.C., Head, G., Jenike, M., Owen, B., Rechtman, R. \& Zechenter, E. (1989) 'Hunting and Gathering in Tropical Rain Forest: Is it possible?', American Anthropologist, Vol. 91, No. 1, pp. 59-82.

Bailey, R. (2005) 'Under the Spell of Malthus’, Reason, Vol. 37, No. 4, pp. 67-71.

Baines, G.B.K. (1994) 'Conservation issues in Oceania: Prospects for Conservation of Biological Diversity in the Pacific Island Region', in C. Moritz \& J. Kikkawa, eds., Conservation Biology in Australia and Oceania, Chipping Norton, NSW, Surrey Beatty \& Sons Pty Limited, pp. 181-185.

Bayliss-Smith, T., Bedford, R., Brookfield, H. \& Latham, M. (1988) Islands, Islanders, and the World: The Colonial and Post-Colonial Experience of Eastern Fiji, Cambridge, Cambridge University Press.

Bertram, G. (1985) 'The MIRAB Economy in South Pacific Microstates', Pacific Viewpoint, Vol. 26, No. 3, pp. 497-512.

Birkeland, C. (2004) 'Ratcheting down the Coral Reefs', BioScience, Vol. 54, No. 11, pp. 1021-1027.

Boserup, E. (1965) The Conditions of Agricultural Growth: The Economics of Agrarian Change Under Population Pressure, New York, Aldine.

Brookfield, H.C. (2001) 'Intensification and Alternative Approaches to Agricultural Change’, Asia Pacific Viewpoint, Vol. 42, No. 2, pp. 181-192.

Brookfield, H.C. \& Overton, J. (1988) 'How old is the Deforestation of Oceania?', in J. Dargavel, K. Dixon \& N. Semple, eds., Changing Tropical Forests, Canberra, Centre for Resource and Environmental Studies, Australian National University, pp. 89-102.

Clark, J.T. \& Kelly, K.M. (1993) 'Human Genetics, Paleoenvironments, and Malaria: relationships and implications for the settlement of Oceania’, American Anthropologist, Vol. 95, No. 3, pp. 612-630.

Clarke, W.C. (1990) 'Learning from the Past: Traditional Knowledge and Sustainable Development', The Contemporary Pacific, Vol. 2, No. 2, pp. 233-253.

Connell, J. (1999) 'Urban Dilemmas', in M. Rapaport, ed. The Pacific Islands: Environment and Society, Honolulu HI, Bess Press, pp. 326-335.

Connell, J. (2003) 'Losing Ground: Tuvalu, the Greenhouse Effect, and the Garbage Can’, Asia-Pacific Viewpoint, Vol. 44, No. 2, pp. 89-107.

Cox, P.A. \& Elmqvist, T. (2000) 'Pollinator Extinction in the Pacific Islands', Conservation Biology, Vol. 14, No. 5, pp. 1237-1239. 
Cronon, W. (1983) Changes in the Land: Indians, Colonists, and the Ecology of New England, New York, Hill \& Wang.

Denham, T. (2005) 'Food for Thought', Nature Australia, Vol. 28, No. 4, pp. 50-55.

Diamond, J.M. (1989) 'Present, Past and Future of Human-caused Extinctions', Philosophical Transactions of the Royal Society of London, B325, pp. 469-477.

Diamond, J.M. (1997) Guns, Germs, and Steel: the Fate of Human Societies, New York, Norton.

Diamond, J.M. (2005) Collapse: How Societies Choose to Fail or Succeed, New York, Viking Press.

Diamond, J.M. \& Bellwood, P. (2003) 'Farmers and their Languages: The First Expansions’, Science, Vol. 300, Issue 5619, pp. 597-603.

Firth, R. (1967) The Work of the Gods in Tikopia, New York, Humanities Press.

Fisher, C.T. \& Feinman, G.M. (2005) 'Introduction to "Landscapes over Time”, American Anthropologist, Vol. 107, No. 1, pp. 62-69.

Flannery, T.F. (1994) The Future Eaters: an Ecological History of the Australasian Lands and People, New York, George Braziller.

Geist, H.J. \& Lambin, E.F. (2002) Proximate Causes and underlying Driving Forces of Tropical Deforestation', Bioscience, Vol. 52, Issue 2, pp. 143-153.

Gibbons, A. (2001) 'The Peopling of the Pacific', Science, Vol. 291, No. 5509, pp. 17351737.

Golson, J. (1997) 'From Horticulture to Agriculture in the New Guinea Highlands: A Case Study of People and their Environments, in P.V. Kirch \& T.L. Hunt, eds., Historical Ecology in the Pacific Islands: Prehistoric Environmental and Landscape Change, New Haven, Connecticut, Yale University Press, pp. 38-50.

Green, R.C. (1991) 'Near and Remote Oceania: Disestablishing "Melanesia” in Culture and History', in A. Pawley, ed., Man and a Half: Essays in Pacific Anthropology and Ethnobiology in Honour of Ralph Bulmer, Auckland, Polynesian Society, pp. 491-502.

Hardin, G. (1968) 'The Tragedy of the Commons', Science, Vol. 162, Issue 3859, pp. 1243-1248.

Hughes, T.P., Baird, A.H., Bellwood, D.R., Card, M., Connolly, S.R., Folke, C., Grosberg, R., Hoegh-Guldberg, O., Jackson, J.B.C., Kelypas, J., Lough, J.M., Marshall, 
P., Nystrom, M., Palumbi, S.R., Pandolfi, J.M., Rosen, B. \& Roughgarden, J. (2003) 'Climate Change, Human Impacts, and the Resilience of Coral Reefs', Science, Vol. 301, Issue 5635, pp. 929-933.

Hunter-Anderson, R. (1998) 'Human versus Climatic Impacts at Rapa Nui: Did the People really cut down all those Trees?', in C.M. Stevenson, G. Lee, F.J. Morin, eds., Easter Island in Pacific Context: South Seas Symposium: Proceedings of the Fourth International Conference on Easter Island and East Polynesia, Easter Island Foundation.

Johannes, R.E. (2002) 'The Renaissance of Community-based Marine Resource Management in Oceania', Annual Review of Ecology and Systematics, Vol. 33, pp. 317340.

Kirch, P.V. (1994) The Wet and the Dry: Irrigation and Agricultural Intensification in Polynesia, Chicago IL, University of Chicago Press.

Kirch, P.V. (1997) 'Microcosmic Histories: Island Perspectives on "global” Change', American Anthropologist, Vol. 99, No. 1, pp. 30-42.

Kirch, P.V (2000) On the Road of the Winds: An Archaeological History of the Pacific Islands before European Contact, Berkeley CA, University of California Press.

Kirch, P.V. \& Yen, D.E. (1982) Tikopia: The Prehistory and Ecology of a Polynesian Outlier. Bernice P. Bishop Museum Bulletin, Vol. 238, Honolulu, Bishop Museum.

Latinis, D.K. (2000) 'The Development of Subsistence System Models for Island Southeast Asia and Near Oceania: The Nature and Role of Arboriculture and Arborealbased Economies', World Archaeology, Vol. 32, No. 1, pp. 41-67.

MacArthur, R.H. \& Wilson, E.O. (1967) The Theory of Island Biogeography, Monographs in Population Biology 1, Princeton, Princeton University Press.

Martin, P.S. \& Steadman, D.W. (1999) 'Prehistoric Extinctions on Islands and Continents', in R.D.E. MacPhee, ed., Extinctions in Near Time, New York, Kluwer, pp. 17-55.

McNeill, J. (1994) 'Of Rats and Men: A Synoptic Environmental History of the Island Pacific’, Journal of World History, Vol. 5, No. 2, pp. 299-349.

Miles, J. (1997) Infectious Disease: Colonizing the Pacific?, Dunedin, University of Otago.

Neumann, K. (2003) 'New Guinea: A Cradle of Agriculture', Science, Vol. 301, Issue 5630, pp. 180-181. 
Nunn, P. (1997) Keimami Sa Vakila na Liga ni Kalou (Feeling the Hand of God): Human and Nonhuman Impacts on Pacific Island Environments, Suva, University of the South Pacific.

Nunn, P. (1999) Environmental Change in the Pacific Basin: Chronologies, Causes, Consequences, London, Wiley.

Nunn, P. (2003a) 'Nature-society Interactions in the Pacific Islands, Geografiska Annaler, Vol. 85B, No. 4, pp. 219-229.

Nunn, P. (2003b) 'Through a Mist on the Ocean: Human Understanding of Island Environments', Tijdschrift vooor Economische en Sociale Geografie, Vol. 95, No. 3, pp. 311-325.

Quammen, D. (1996) The Song of the Dodo, New York, Scribner.

Rainbird, P. (2002) 'A Message to our Future? The Rapa Nui (Easter Island) Ecodisaster and Pacific Island Environments’, World Archaeology, Vol. 33, No. 3, pp. 436-451.

Rallu, J. (1990) Les Populations Océaniennes aux XIX et XXe Siècles, Paris, INED.

Rallu, J-L. \& Ahlburg, D.A. (1999) 'Demography', in M. Rapaport, ed., The Pacific Islands: Environment and Society, Honolulu, Bess Press, pp. 258-269.

Rapaport, M. (1999) 'Mobility', in M. Rapaport, ed., The Pacific Islands: Environment and Society, Honolulu HI, Bess Press, pp. 270-281.

Rolett, B. \& Diamond, J. (2004) 'Environmental Predictors of pre-European Deforestation on Pacific Islands’, Nature, Vol. 431, September, pp. 443-446.

Saulei, S.M (1994) 'Forest Resources and Conservation in Oceania', in C. Moritz \& J. Kikkawa, eds., Conservation Biology in Australia and Oceania, Chipping Norton, NSW, Surrey Beatty \& Sons Pty Limited, pp. 187-195.

Sessions, L. (2003) ‘Date with Extinction’, Natural History, Vol. 112, Issue 3, pp. 52-58.

Shapiro, K. (2005) 'Scorched Earth: Collapse: How Societies Choose to Fail or Succeed by Jared Diamond’, Commentary, April, pp. 85-88.

Sharp, A. (ed.) (1970) The Journal of Jacob Roggeveen, Oxford, Clarendon Press.

Smith, E.A. \& Wishnie, M. (2000) 'Conservation and Subsistence in small-scale Societies', Annual Review of Anthropology, Vol. 29, pp. 493-524. 
Spriggs, M. (1999) 'Comment: Pacific Archaeologies: Contested Ground in the Construction of Pacific History', The Journal of Pacific History, Vol. 34, No. 1, pp. 109121.

Stone, G.D. (2001) 'Agricultural Change Theory', International Encyclopedia of the Social and Behavioral Sciences, Oxford, Elsevier Science.

Thomas, F.R. (1999) 'The Precontact Period', in M. Rapaport, ed., The Pacific Islands: Environment and Society, Honolulu, Bess Press, pp. 121-133.

Turnbull, J. (2004) 'Explaining Complexities of Environmental Management in Developing Countries: Lessons from the Fiji Islands', The Geographical Journal, Vol. 270, No. 1, pp. 64-77.

Volman, T. (1978) 'Early Archaeological Evidence for Shellfish Collecting', Science, Vol. 201, pp. 911-913.

Watson, D.M. (2002) 'A Conceptual Framework for studying Species Composition in Fragments, Islands and other Patchy Ecosystems', Journal of Biogeography, Vol. 29, No. 5/6, pp. 823-834.

Whittaker, R.J. (1998) Island Biogeography: Ecology, Evolution, and Conservation, Oxford, Oxford University Press.

Wiessner, P. (2002) 'The Vines of Complexity: Egalitarian Structures and the Institutionalization of Inequality among the Enga', Current Anthropology, Vol. 43, No. 2, pp. 233-269.

Worster, D. (1992) Under Western Skies: Nature and History, and the American West, New York, Oxford University Press. 